\title{
Aydın İlinde Tüketime Sunulan Çöp Şişlerin Mikrobiyolojik Kalitesinin Incelenmesi
}

\author{
Hilal Demirpençe, Devrim Beyaz, Sadık Savaşan \\ Aydın Adnan Menderes Üniversitesi, Veteriner Fakültesi, Bes. Hij. ve Tek. AD, Aydın.
}

Geliş Tarihi / Received: 23.01.2019, Kabul Tarihi / Accepted: 30.04.2019

\begin{abstract}
Özet: Bu çalışmada, yaz ve kış dönemlerinde Aydın ilinde çeşitli restoranlardan toplanan 100 adet çöp şiş örneği mikrobiyolojik özellikleri bakımından incelenmiştir. Mikrobiyolojik analizler sonucunda TMACB sayıları değerlendirildiğinde kış mevsiminde 4.14-7.12 log kob/g arasında ve ortalama $5.53 \mathrm{log} \mathrm{kob} / \mathrm{g}$ olarak bulunmuştur. Yaz mevsiminde ise, 4.50-7.81 log kob/g arasında ve ortalama $6.33 \mathrm{log}$ kob/g olarak saptanmıştır. Çöp şişlerden elde edilen Staphylococcus aureus sayıları değerlendirildiğinde; kış ayında $<2$ ile $5.81 \mathrm{log} \mathrm{kob} / \mathrm{g}$ arasında ve ortalama olarak $5.04 \mathrm{log} \mathrm{kob} / \mathrm{g}$, yaz ayında ise $<2$ ile $6.07 \mathrm{log} \mathrm{kob} / \mathrm{g}$ arasında ve ortalama $4.80 \mathrm{log} \mathrm{kob} / \mathrm{g}$ olarak bulunmuştur. Kış ayında 50 adet çöp şiş örneğinin 16 tanesinde (\% 32), yaz ayında 50 adet çöp şiş örneğinin 30 tanesinde (\% 60) S. aureus tespit edilmiştir. Çalışmadaki koliform bakteri sayıları incelendiğinde ise, belirlenen dilüsyon oranlarında yaz mevsiminde 2-6.23 log $\mathrm{kob} / \mathrm{g}$ sayıları arasında ve ortalama olarak $4.83 \mathrm{log} \mathrm{kob} / \mathrm{g}$ olarak, kış mevsiminde $<2-5.21 \log \mathrm{kob} / \mathrm{g}$ arasında ve ortalama $3.93 \mathrm{log} \mathrm{kob} / \mathrm{g}$ olarak bulunmuştur. E. coli sayıları değerlendirildiğinde ise, yaz döneminde minimum $<2$, maksimum $4.51 \mathrm{log} \mathrm{kob} / \mathrm{g}$ ortalama $3.65 \mathrm{log} \mathrm{kob} / \mathrm{g}$ olarak tespit edilmiștir. Maya küf sayıları değerlendirildiğinde yaz ayında 2.84$6.19 \log \mathrm{kob} / \mathrm{g}$ aralığında ve ortalama $4.88 \mathrm{log} \mathrm{kob} / \mathrm{g}$, kış ayında ise $<2-5.54 \log \mathrm{kob} / \mathrm{g}$ aralığında ortalama olarak 4.47 $\log \mathrm{kob} / \mathrm{g}$ olarak tespit edilmiştir. Bununla birlikte yaz ayında 50 numunenin 6 tanesinde (\% 12), kış ayında ise 50 numunenin 1 tanesinde (\% 2) Salmonella spp. varlığı tespit edilmiştir. Bu çalışmanın sonucunda çöp şiş örneklerinin üretimi esnasında, kırmızı etin kesiminden tüketime gelinceye kadar hijyenik koşullara yeterince uyulmaması sebebiyle mikrobiyolojik kriterlerin genel olarak yetersiz olduğu belirlenmiştir. Çöp şiş örneklerinde gıda enfeksiyonlarına sebep olan S. aureus, Salmonella spp. ve koliform grubu bakterilerin bulunması halk sağlığı açısından risk teşkil etmektedir.
\end{abstract}

Anahtar kelimeler: Çöp şiş, halk sağlı̆̆ı, mikrobiyal kalite.

\section{Examination of the Microbiological Quality of Çöp Şiş Available for Consumption in the Province of Aydın}

\begin{abstract}
In this study, 100 samples of çöp şiş collected from a variety of restaurants in the summer and winter seasons were examined in terms of microbiological properties in the province of Aydin. When microbiological analysis results are evaluated considering the numbers TVC in the winter season between 4.14 to $7.12 \mathrm{log} \mathrm{cfu} / \mathrm{g}$ and an average 5.53 $\log \mathrm{cfu} / \mathrm{g}$, in the summer season, between 4.50-7.81 log cfu/g and an average $6.33 \mathrm{log} \mathrm{cfu} / \mathrm{g}$. When the numbers of $S$. aureus obtained from çöp şiş evaluated; in the winter season $<2$ to $5.81 \mathrm{log} \mathrm{cfu} / \mathrm{g}$ and averaged $5.04 \mathrm{log} \mathrm{cfu} / \mathrm{g}$, while in the summer season $<2$ to $6.07 \log \mathrm{cfu} / \mathrm{g}$, and $4.80 \mathrm{per} \log \mathrm{cfu} / \mathrm{g}$, respectively. In the winter 16 of 50 çöp şiş samples, (32 $\%)$, in the summer 30 of 50 çöp şiş samples $(60 \%)$ S. aureus have been identified. When the number of coliform bacteria examined in the study, in the summer season between 2-6.23 log cfu/g, number in the specified dilution rates and average $4.83 \log \mathrm{cfu} / \mathrm{g}$, in the winter season $<2$ between $5.21 \log \mathrm{cfu} / \mathrm{g}$, and an average of $3.93 \mathrm{log} \mathrm{cfu} / \mathrm{g}$, respectively. When the number of $E$. coli assessed, in the summer minimum of $<2$, max of $4.51 \log \mathrm{cfu} / \mathrm{g}$ and $3.65 \log \mathrm{cfu} / \mathrm{g}$ was determined. When the yeast and mold counts evaluated in the summer 2.84-6.19 log cfu/g and an average range of $4.88 \mathrm{log} \mathrm{cfu} / \mathrm{g}$, while in the winter $<2-5.54 \log \mathrm{cfu} / \mathrm{g}$ in the range of 4.47 average $\log \mathrm{cfu} / \mathrm{g}$ was determined. Our study Salmonella spp. in terms of presence in the summer season in 6 of 50 samples $(12 \%)$, while in the winter season of 1 out of 50 samples (2\%) Salmonella spp. presence was detected. The results of this study, during the production of çöp şiş samples, until the cut consumption of red meat because it was determined that enough non-observance of hygienic conditions microbiological criteria is generally inadequate. In the examples of çöp şiş that cause food infections of S. aureus, Salmonella spp. and coliform bacteria poses a risk to public health.
\end{abstract}

Key words: Çöp şiş, public health, microbial quality.

\section{Giriș}

Çöp şiş, dana etinin yumuşak kısımlarının şişlere dizilip pişirilmesiyle tüketilen, besin değeri oldukça yüksek olan ve Ege Bölgesi'nde ve özellikle Aydın ilinde sıklıkla tüketilen yöresel bir yemek çeşididir ve tarihi 140 yll öncesine dayanmaktadır. 
İzmir-Aydın demiryolu yapımında görev alan mühendisler farklı yemek kültürleri nedeniyle geçmiş zamanlarda zorluklar yaşamışlardır. Beslenme konusunu günlerce düşünmüşler ve en riski en az olan yemeğin çubuklara taktıkları etleri ateşte pişirerek tüketmek olduğunu bulmuşlardır. İngiliz mühendislerin sürekli bu etleri yediğini gören Egeliler bu yemeği zamanla kendileri yaparak satmaya başlamışlardır. Yıllar önce Cumhuriyet Gazetesi'nin Pazar ekinde bir yazıda Ortaklar ilçesindeki gelir düzeyi düşük ailelerin çocuklarının boyunlarına astıkları mangallarla mühendislere çöp şiş sattıkları yayınlanmıştır. $\mathrm{Bu}$ tat 140 yıldır özellikle Aydın ili Ortaklar ilçesinin değişmeyen lezzeti olmuştur [23].

Kırmızı et yüksek protein içeriği, su aktivitesi ve $\mathrm{pH}$ seviyesi nedeniyle bakterilerin gelişmesi ve hayatta kalması için elverişli koşullar sağlamakta, gıda kaynaklı zehirlenmeler açısından potansiyel bir tehlike oluşturmaktadır [11]. Kesim prosesinin başında karkasların yüzeyi steril kabul edilmekle birlikte, prosesin devaminda yüzeysel kontaminasyon kaçınılmaz bir hal almaktadır. Kesim sırasında, kesim sonrası taşıma, depolama, parçalama işlemleri ile hem karkas yüzeyi değişik türde bozulmaya neden olan hem de bağırsak orjinli patojen bakterilerle kontamine olmaktadır $[10,16,19]$.

Gida maddelerinin mikrobiyolojik kriterlerinin belirlenmesinde toplam mezofilik aerobik can11 bakteri (TMACB), koliform grubu bakteriler, $E$. coli, S. aureus, fekal Streptococcus, Clostridium perfiringes ve maya küf sayıları ile Salmonella spp. varlığı dikkate alınmaktadır [13].

$\mathrm{Bu}$ çalışma, Aydın ili ve ilçelerinde çeşitli işletmelerde satışa sunulan çöp şişlerin yaz ve kış mevsimlerine göre mikrobiyolojik kalitesinin araştırılması ve halk sağlığı açısından değerlendirilmesi amacıyla yapılmıştır.

\section{Materyal ve Metot}

Çalışmada Aydın ilinde Ağustos ve Kasım aylarında restoranlardan temin edilen 100 adet çiğ çöp şiş numunesi, her bir numuneden 100 gram olacak şekilde steril poşetler içinde soğuk zincir altında Adnan Menderes Üniversitesi, Veteriner Fakültesi Besin/ Gıda Hijyeni ve Teknolojisi Anabilim Dalı laboratuvarına getirilerek Toplam Mezofilik Aerobik Canlı Bakteri (TMACB), S. aureus, koliform bak- teri, E. coli, maya-küf sayıları ile Salmonella spp. varlığı yönüyle incelendi.

Toplanan çöp şiş örneklerinden aseptik şartlarda alınan 10'ar gram numune, içerisinde 90 $\mathrm{ml}$ steril fizyolojik peptonlu su (Labkim T73029, Fluka 70179) bulunan stomacher torbalarına konulup Stomacher (Bag mixer, Interscience, France) içerisinde 2 dakika boyunca homojenize edildi. Homojenize edilen çöp şiş örneklerinden TMACB, E.coli, koliform ve $S$. aureus sayıları için seri dilüsyonlar hazırlandi.

\section{TMACB Sayısının Belirlenmesi}

Elde edilen dilüsyonlardan Plate Count Agar'a (OXOID CM463) yüzeyde yayma plak yöntemi kullanılarak inokulasyonlar yapıldı ve petri kutuları $37^{\circ} \mathrm{C}$ ' de 24 saat inkübasyona bırakı1dı. İnkübasyon sonunda sonuçlar koloni oluşturan birim/gram (kob/g) olarak değerlendirildi $[4,14]$.

\section{S. aureus Sayısının Belirlenmesi}

Çöp şiş örneklerinde $S$. aureus sayısını belirlemek için TSE 6582-1 ISO 6888-1 standard1 kullanıld1. Hazırlanan dilüsyonlardan Egg yolk - Tellurite Emulsion (OXOID SR0054C) içeren Baird Parker Agar' a (OXOID CM275) yüzeyde yayma plak yöntemiyle ekim yapıldı. Ekim yapılan BPA içeren petri kutular $37^{\circ} \mathrm{C}^{\prime}$ de $24-48$ saat inkübe edidikten sonra etrafı şeffaf zonla çevirili, gri ve siyah renkli koloniler S. aureus şüpheli koloniler olarak belirlendi. Şüpheli $S$. aureus kolonileri DNaz agara (OXOID CM0321) öze ile inkübe edildi ve $37^{\circ} \mathrm{C}^{\prime}$ de 24 saat inkübe edildi. İnkübasyon sonrası petri yüzeyini kaplayacak biçimde $1 \mathrm{~N} \mathrm{HCl}$ eklendi ve DNA'nın $\mathrm{HCl}$ ile muamelesi sonrası presipitasyon varlığ 1 incelendi. DNA'nın mikroorganizmalar tarafından kullanılmayan bölgeleri mat, DNA' in parçaladığ bölgelerde şeffaf zonlar gözlendi. Yine şüpheli $S$. aureus kolonileri Mannitol Salt Agar' a (OXOID CM0085) öze yardımıyla geçildi. Besiyerinin fenol kırmızısı renginin sarıya dönmesi pozitif olarak değerlendirildi. Pozitif örneklerin doğrulaması Dryspot (OXOID DR0100M) ile yapıldı [17].

\section{Koliform ve $\boldsymbol{E}$. coli Sayısının Belirlenmesi}

Koliform ve E. coli sayısının belirlenmesi için hazırlanan dilüsyonlardan Violet Red Bile Agar 'a (OXOID CM0107) çift katlı dökme plak ekim yön- 
temi kullanılarak ekim yapılmış ve $37^{\circ} \mathrm{C}^{\prime}$ de 48 saat inkübe edildikten sonra kırmızı renkli koloniler koliform bakteri değerlendirildi ve $E$. coli için tipik (kırmızı renkli etrafı pembe zonlu) olan koloniler seçilerek $44^{\circ} \mathrm{C}$ ' de 24 saat içerisinde asit (laktik asit) ve gaz $\left(\mathrm{CO}_{2}\right)$ oluşturma testi ve IMVIC testleri uyguland 199,14$]$.

\section{Salmonella spp. İzolasyon ve İdentifikasyonu}

Aseptik olarak alınan, soğuk zincir altında labaratuvara getirilen çöp şiş örneklerinde Salmonella spp. varlığının tespiti TSE ISO 6579 standardı kullanılarak yapıldı. Her bir örnekten steril stomacher torbalarına 25' er gram çöp şiş konularak $225 \mathrm{ml}$ tamponlanmış peptonlu su (OXOID CM509) içerisinde 2 dakika stomacherde homojenize edildikten sonra $37^{\circ} \mathrm{C}^{\prime}$ de 24 saat inkübe edildi. Ön zenginleştirme işleminden sonra her bir çöp şiş numunesinden $0.1 \mathrm{ml}$ alınarak $10 \mathrm{ml}$ Rappaport-Vassiliadis Enrichment Broth (OXOID CM0669) içeren tüplere inokule edilerek $42^{\circ} \mathrm{C}^{\prime}$ de 24 saat inkübasyona birakıldı. İnkübasyon sonunda her tüpten yuvarlak uçlu öze ile bir öze dolusu alınarak Deoxycholalete Agar' a inakulasyonlar yapıldı ve inakule edilen petri kutular $37^{\circ} \mathrm{C}$ ' de 24 saat inkübe edildi. İnkübasyon süresi sonunda oluşan pembe renkli ve siyah merkezli şüpheli koloniler biyokimyasal testler ve Salmonella Latex Test (OXOID FT 0203A) kiti kullanılarak değerlendirildi [17].

\section{Maya ve Küf Sayısının Belirlenmesi}

Maya ve küf sayılarının tespiti için steril \% 10' luk tartarik asit çözeltisi ile pH's1 3,5' e ayarlanmış Potato Dextrose Agar (OXOID 0139) kullanilarak yayma plak ekim yapild 1 ve $21 \pm{ }^{\circ} \mathrm{C}$ ' de 5 gün petriler inkübe edildikten sonra sonuçlar değerlendirildi [18].

\section{Bulgular}

$\mathrm{Bu}$ araştırmada çöp şiş örnekleri TMACB, $S$. aureus, Koliform Bakteri, E. coli, ve maya küf say1ları ile Salmonella spp. varlığı yönünden mevsimsel olarak incelenmiş olup analiz sonuçları Tablo 1 ve Tablo 2 'de gösterilmiştir.

İncelenen örneklerde Tablo 1'de görüldügü gibi TMACB sayis1, total koliform bakteriler E. coli, $S$. aureus, ve maya küf sayılarının yaz ayındaki orta- lamaları sırasıyla $6.33,4.83,3.65,4.80,4.88 \log _{10}$ kob/g düzeyinde saptanmıștır. Kış ayında ise Tablo 2'de görüldüğü gibi TMACB sayıs1, total koliform bakteriler, E. coli, S. aureus, ve maya küf say1larının ortalamalarının sirasiyla 5.53, 3.93, $<2,5.04$, $4.47 \log _{10} \mathrm{kob} / \mathrm{g}$ düzeyinde olduğu bulunmuştur. Yaz ayında incelenen 50 adet çöp şiş örneğinin 12 tanesi (\% 24) E.coli, 30 tanesi (\% 60) ise S. aureus açısından pozitif olarak bulunmuştur. Kış ayında incelenen 50 adet örneğinin 16 tanesinde (\% 32) $S$. aureus pozitif bulunurken, örneklerin hiçbirisinde E. coli varlığına rastlanılmamıştır.

İncelenen toplam 100 adet çöp şiş örneğinin yaz ayında 6 tanesinde (\% 12) Salmonella spp. varlığına rastlanırken, kış ayında örneklerin 1 tanesinde (\% 2) Salmonella spp. saptanmıştır.

\section{Tartışma ve Sonuç}

Çöp şişlerden elde edilen TMACB sayıları kış mevsiminde 4.14-7.12 log kob/g arasinda ve ortalama $5.53 \mathrm{log} \mathrm{kob} / \mathrm{g}$, yaz mevsiminde ise, 4.50-7.81 log $\mathrm{kob} / \mathrm{g}$ arasinda ve ortalama $6.33 \mathrm{log} \mathrm{kob} / \mathrm{g}$ olarak bulunmuştur. David ve ark. [7] Avustralya'da yaptıkları bir çalışmada 360 adet kırmızı et numunesinde TMACB sayısını 5.79 log kob/g olarak tespit etmişlerdir. Cohen ve ark. [5] tarafindan Kazablanka'da mezbahalarda, kasaplarda ve süpermarketlerde mevsimsel olarak 26'şar adet parça kırmızı et örneklerinden elde ettikleri çalışmada TMACB sayısı mezbahalarda kış mevsiminde ortalama $5.1 \mathrm{log}$ kob/g, yaz mevsiminde 5.2 log kob/g, kasaplardan aldıkları parça kırmızı et örneklerinde kış mevsiminde ortalama $6.5 \mathrm{log} \mathrm{kob} / \mathrm{g}$, yaz mevsiminde 7.3 $\log \mathrm{kob} / \mathrm{g}$, süpermarketlerden aldıkları et örneklerinde ise kış mevsiminde ortalama $7.1 \mathrm{log} \mathrm{kob} / \mathrm{g}$, yaz mevsiminde $7.3 \mathrm{log} \mathrm{kob} / \mathrm{g}$ olarak belirlenmiştir. Nursoy ve Akgün [16] tarafindan Ankarada' ki askeri birliklerin ihtiyacı için alınan karkaslardaki TMACB say1s1 4.57-6.92 log kob/g arasinda ve ortalama $5.71 \log \mathrm{kob} / \mathrm{g}$ olarak, parçalamadan sonra ise TMACB sayıs1 4.93-7.89 log kob/g arasinda ve ortalama $6.20 \mathrm{log} \mathrm{kob} / \mathrm{g}$ olarak bulunmuştur. Akan [1] et ve et ürünleri ile ilgili yaptığı bir çalışmada 16 adet parça et numunesinin TMACB sayısını 3.71$7.74 \mathrm{log} \mathrm{kob} / \mathrm{g}$ arasinda ve ortalama $5.76 \mathrm{log} \mathrm{kob} / \mathrm{g}$ olarak belirlemiştir. Tuncer [22] tarafindan yapılan Bitlis ili ve çevresinde askeri mutfaklarda kullanı- 
lan sığır etleri ile ilgili çalışmada 100 adet örneğin TMACB sayisı ortalama olarak 4.15 olarak bulunmuştur. Thomas ve ark. [21] tarafından Etiyopya' da yapılan bir çalışmada belediye kesimhanesinde 55 adet kırmızı et örneğinin TMACB sayısı $1.27 \times 10^{5}$ $1.05 \times 10^{7} \mathrm{kob} / \mathrm{g}$ arasinda ve ortalama olarak 6.35 $\log \mathrm{kob} / \mathrm{g}$, restoranlardan alınan 55 adet et örneğinin TMACB say1s1 $1.08 \times 10^{5}-2.00 \times 10^{7} \mathrm{kob} / \mathrm{g}$ arasında ve ortalama $6.45 \log \mathrm{kob} / \mathrm{g}, 3$ adet bölgesel marketten alınan 50'şer adet et örneğin ortalama TMACB sayıları ise 6.8, 6.78, $6.77 \mathrm{log} \mathrm{kob} / \mathrm{g}$ olarak belirlenmiştir.

Genel hijyen ve mikrobiyal yükün belirlenmesinde indikatör olarak kullanılan TMACB sayısının yüksek olması halinde diğer mikroorganizma gruplarının sayısı da yüksek olmaktadır. Gıdalarda bulunan insan ve hayvan kaynaklı birçok patojen mikroorganizma mezofilik yapıda olmakta ve aerobik ya da fakültatif anaerobik koşullarda üremektedirler. Ürünlerde aerobik mezofilik mikroorganizma say1sının yüksek olması, patojenlerin bulunma olasılığ1nın yüksek olduğunu göstermektedir [14].

Çöp şişlerden elde edilen $S$. aureus sayıları değerlendirildiğinde; kış ayında $<2$ ile $5.81 \log$ ko$\mathrm{b} / \mathrm{g}$ arasinda ve ortalama olarak $5.04 \mathrm{log} \mathrm{kob} / \mathrm{g}$, yaz ayında ise $<2$ ile $6.07 \mathrm{log} \mathrm{kob} / \mathrm{g}$ arasinda ve ortalama $4.80 \log \mathrm{kob} / \mathrm{g}$ olarak bulunmuştur. Bununla birlikte yaz ayında 30 adet numunede $(\% 60) \mathrm{S}$. aureus pozitif olarak, kış ayında ise 16 numunede (\% 32) $S$. aureus pozitif olarak tespit edilmiştir.

David ve ark. [7] Avustralya'da yaptıkları çalışmada 360 adet kırmızı et numunesinde $S$. aureus sayısını $2.18 \log \mathrm{kob} / \mathrm{g}$ olarak belirlemişlerdir. Çıtak ve ark. [6] yaptıkları bir çalışmada 20 adet kuşbaş1 örneğinde $S$. aureus sayısını $5.63 \mathrm{log}$ kob/g olarak bulmuşlardır. Özdemir [19] sığır karkaslarının mikrobiyel yükünün belirlenmesi çalışmasında $S$. aureus say1sin1 maksimum 4.38, minimum 3.14, ortalama $3.85 \log \mathrm{kob} / \mathrm{cm}^{2}$ olarak bulmuştur. Al-Jassas [2] tarafından yapılan bir çalışmada kasap ve marketlerden alınan kırmızı et örnekleri $4^{\circ} \mathrm{C}$ 'de 5 gün depolanmış ve depolama sonunda mikrobiyel yük değerlendirilmiştir. Yaz mevsiminde süpermarketlerden temin edilen kırmızı et örneklerinde $S$. aureus sayıs1 5. günün sonunda $4.2 \log \mathrm{kob} / \mathrm{g}$, kasaplardan temin edilen örneklerde ise $5.8 \mathrm{log} \mathrm{kob} / \mathrm{g}$ olarak bulunmuştur. Kış mevsiminde ise, süpermarketlerden alınan kırmızı et örneklerinde $S$. aureus sayısı 3.3 $\log \mathrm{kob} / \mathrm{g}$, kasaplardan alınan örneklerde $4.0 \log$ kob/g olarak bulunmuştur. Çalışmada $S$. aureus'un düşük düzeyde saptanmasının, yüksek toplam mezofilik aerobik bakteri sayısından kaynaklanabileceği öngörülmektedir. Bunun sebebi $S$. aureus'un rekabetçi özelliği zayıf bir bakteri olması ve gıda da başlangıçtaki sayısı yüksek olmadığı durumlarda iyi gelişememesidir [3].

Bu çalışmada kış mevsiminde $S$. aureus sayısınin yaz mevsimine oranla daha az olmasinın sebebi; mevsimsel sicaklıklar arasındaki farklılıktandir. Ayrıca mikroorganizmaların üremesini etkileyen diğer faktörlerden olan $\mathrm{pH}, \mathrm{a}_{\mathrm{w}}$, atmosfer şartları, diğer organizmaların varlığı da sonuçları etkilemiş olabileceği düşünülmektedir.

Çalışmadaki koliform bakteri sayıları incelendiğinde ise, belirlenen dilüsyon oranlarında yaz mevsiminde 2-6.23 log kob/g say1ları arasında ve ortalama olarak $4.83 \mathrm{log} \mathrm{kob} / \mathrm{g}$ olarak, kış mevsiminde $<2-5.21 \log \mathrm{kob} / \mathrm{g}$ arasinda ve ortalama 3.93 $\log \mathrm{kob} / \mathrm{g}$ olarak bulunmuştur. Cohen ve ark. [5] tarafından Kazablanka'da yapılan bir araştırmada kesimhanelerden, kasaplardan ve süpermarketlerden 26 'şar adet et numuneleri yaz ve kış mevsimlerinde temin edilmiştir. Kesimhanelerden alınan örneklerde toplam koliform sayısı yaz ve kış mevsimlerinde $1.6 \log \mathrm{kob} / \mathrm{g}$ olarak, kasaplardan alınan örneklerde yaz mevsiminde $3.7 \mathrm{log} \mathrm{kob} / \mathrm{g}$, kış mevsiminde 2.8 log kob/g olarak, süpermarketlerden alınan örneklerde ise, yaz mevsiminde 3.2, kış mevsiminde 1.4 $\log \mathrm{kob} / \mathrm{g}$ olarak tespit edilmiştir. Nursoy ve Akgün [16] tarafından sığır etlerinin mikrobiyolojik kriterleri üzerine yapılan bir çalışmada ise 30 adet karkas örneğinde toplam koliform bakteri say1s1 3.07- 5.20 $\log \mathrm{kob} / \mathrm{g}$ değerleri arasında ve ortalama olarak 4.07 $\log \mathrm{kob} / \mathrm{g}$ bulunmuş ve parçalama sonrası incelenen 30 adet parça et örneğinde toplam koliform sayıs1 ise, 3.20-6.07 log kob/g aralığında ve ortalama 4.81 $\log \mathrm{kob} / \mathrm{g}$ olarak tespit edilmiştir. Thomas ve ark. [21] tarafında Etiyopya'da yapılan bir araştırmada 260 adet et örneği incelenmiştir. Kesimhanelerden temin edilen 55 adet et örneğinde toplam koliform say1s1 $1.26 \times 10^{3}-2.10 \times 10^{5} \mathrm{kob} / \mathrm{g}$ ve ortalama 4.52 $\log \mathrm{kob} / \mathrm{g}$ olarak bulunmuştur. Restoran ve otellerden temin edilen 55 adet et örneğinde ise toplam koliform say1s1 $1.01 \times 10^{3}-1.18 \times 10^{5} \mathrm{kob} / \mathrm{g}$, ortalama $4.57 \mathrm{log} \mathrm{kob} / \mathrm{g}$ olarak bulunmuştur. 3 adet yerel marketten temin edilen 50'şer adet et örneğinde ise 
toplam koliform sayıları, ortalama $4.76 \mathrm{log} \mathrm{kob} / \mathrm{g}$, $4.48 \log \mathrm{kob} / \mathrm{g}, 4.72 \mathrm{log} \mathrm{kob} / \mathrm{g}$ olarak bulunmuştur. Toplamda 260 adet et örneğinin toplam koliform bakteri sayıs1 sonucu ortalama $4.68 \mathrm{log} \mathrm{kob} / \mathrm{g}$ olarak bulunmuştur. Al-Jasass [2] tarafindan yapılan bir araştırmada kırmızı etin yaz ve kış mevsiminde $4^{\circ} \mathrm{C}^{\prime}$ de 5 gün boyunca depolanmasi sonucunda mikrobiyal değerleri incelenmiştir. İncelenen örneklerde yaz mevsiminde 5. günün sonunda toplam koliform sayısı kasaplardan temin edilenlerde 4.8 $\log \mathrm{kob} / \mathrm{g}$, süpermarketlerden temin edilenlerde ise $3.8 \mathrm{log} \mathrm{kob} / \mathrm{g}$ olarak bulunurken, kış mevsiminde ise, kasaplardan temin edilen örneklerde toplam koliform say1s1 $4.5 \mathrm{log} \mathrm{kob} / \mathrm{g}$, süpermarketten temin edilenlerde ise $3.7 \mathrm{log} \mathrm{kob} / \mathrm{g}$ olarak bulunmuştur.

Gidalarda indikatör mikroorganizmalardan olan toplam koliform varlığı ve bu indikatörün belli bir sınırın üstünde bulunması, ürünlerin yeterli olmayan hijyen ve sanitasyon koşullarında işlendiğini, insan, hayvan, toprak, su ve dışkı kaynaklı bir bulaşma ile kontamine olabilecek koşullarda üretilip tüketime sunulduğunun bir göstergesi olarak kabul edilmektedir [6]. Özellikle fekal kontaminasyonun bir göstergesi olarak kabul edilen koliform bakterilerin karkas ve parça etlerde bu derece yüksek oranlarda bulunuyor olmasının, kesim, taşıma ve parçalama işlemleri esnasında hijyen kurallarına yeterince uyulmamasından ve personelin eğitilmemiş olmasından kaynaklanabileceği düşünülmektedir [16]. Yapılan bu çalışmada E. coli sayıları değerlendirildiğinde ise, yaz ayında 50 adet çöp şiş örneğinin 12 tanesinde (\% 24) E. coli 'ye rastlanılmış, kış mevsiminde ise belirlenen dilüsyon oranlarında $E$. coli 'ye rastlanılmamıştır. Yaz ayında rastlanılan $E$. coli sayıları minimum $<2$, maksimum 4.51 log ko$\mathrm{b} / \mathrm{g}$, ortalama $3.65 \log \mathrm{kob} / \mathrm{g}$ olarak tespit edilmiştir. David ve ark. [7]'nın Avustralya'da yaptıkları çalışmada 360 adet et örneği incelenmiş ve $E$. coli sayısı $1.49 \log \mathrm{kob} / \mathrm{g}$ olarak bulunmuştur. Cohen ve ark. [5]'nın Kazablanka'da yapılan bir çalışmada kesimhaneden alınan 26 adet örnekte yaz mevsiminde E. coli sayıs1 $1.0 \log \mathrm{kob} / \mathrm{g}$, kış mevsiminde ise $1.2 \mathrm{log} \mathrm{kob} / \mathrm{g}$ olarak belirlemişlerdir. Kasaplardan aldıkları 26 adet et örneğinde ise, yaz mevsiminde E. coli sayıs $3.2 \mathrm{log} \mathrm{kob} / \mathrm{g}$, kış mevsiminde $2.4 \mathrm{log}$ kob/g olarak, süpermarketten alınan 26 adet örnekte ise, yaz mevsiminde $2.5 \mathrm{log} \mathrm{kob} / \mathrm{g}$, kış mevsiminde $1.0 \mathrm{log} \mathrm{kob} / \mathrm{g}$ olarak belirlenmiştir. Nursoy ve
Akgün [16] Ankara'da sığır etleri üzerine yapılan bir çalışmada, 30 adet karkasın 18 tanesinde $(\% 60)$ E. coli'ye rastlanmış olup, E. coli sayıları $7.2 \times 10^{2}-$ $9.6 \times 10^{4} \mathrm{kob} / \mathrm{g}$ arasında bulunmuştur. Parçalamadan sonraki 30 adet kırmızı et örneğinin 10 tanesinde (\%33.3) E. coli 'ye rastlanmakla birlikte E. coli say1ları $3.2 \times 10^{2}-7.2 \times 10^{5} \mathrm{kob} / \mathrm{g}$ olarak belirlenmiştir.

Kasaplık hayvanların kesimi esnasında karkas ve organların ikincil kontaminasyonuna neden olan kaynaklar bulunmaktadır. Bunların en önemlisi fekal kontaminasyon olup, özellikle hayvanların bağırsakları kesim esnasında fekal kontaminasyona önemli bir kaynak oluşturmaktadır [20]. İnsan ve hayvanların bağırsaklarında yaşayan $E$. coli, indikatör mikroorganizma olarak kabul edilmekte ve g1dalarda bulunması halinde fekal bir kontaminasyon olduğunun göstergesi olmaktadır. Bu bakterilerin doğal ortamı sıcakkanlı hayvanların bağırsakları olduğundan dolayı her türlü et ve et ürünleri bakterinin bulaşmasında önemli bir etken olmaktadır. Kesimhane hijyeninin etkin olmaması ile kesim esnasında ete bulaşan bakteriler yeterli isıl işlem ile muamele görmezlerse gıdalarda etkinliklerini sürdürerek tüketiciye bulaşmaktadırlar. Bu nedenle gıdanın üretiminden satışına kadar bütün aşamalarında hijyen kurallarına uyulması halk sağlığı açısından oldukça önem taşımaktadır [8].

Çöp şiş örneklerindeki maya küf sayıları değerlendirildiğinde yaz ayında 2.84-6.19 log kob/g aralığında ve ortalama $4.88 \mathrm{log} \mathrm{kob} / \mathrm{g}$, kış ayında ise $<2-5.54 \log \mathrm{kob} / \mathrm{g}$ aralığında ortalama olarak 4.47 $\log \mathrm{kob} / \mathrm{g}$ olarak tespit edilmiştir. Nursoy ve Akgün [16] Ankarada'ki askeri birliklerin ihtiyacı için alınan sığır etlerinin mikrobiyolojik kalitesi üzerine yaptıkları bir çalışmada 30 adet karkas örneğinde maya ve küf sayıs $2.0 \times 10^{2}-3.6 \times 10^{4} \mathrm{kob} / \mathrm{g}$ aralığında ve yine parçalamadan sonraki 30 adet et örneğinde

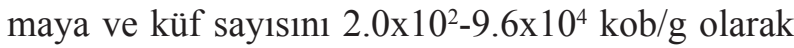
tespit etmişlerdir. Mohamed [15] Sudan' da yaptığ taze et ve et ürünleri ile ilgili çalışmasında 10 adet parça et numunelerinde toplam maya küf sayısını $2.66 \times 10^{3} \mathrm{kob} / \mathrm{g}$ (3.42 log kob/g) olarak bulmuştur.

Çöp şiş numuneleri Salmonella spp. varlığı açısından değerlendirildiğinde yaz ayında $50 \mathrm{nu}-$ munenin 6 tanesinde (\%12), kış ayında ise $50 \mathrm{nu}-$ munenin 1 tanesinde (\%2) Salmonella spp. varlığ tespit edilmiştir. Tuncer [22] Bitlis ili ve çevresindeki askeri mutfaklarda kullanılan sığır gövde et- 
lerinde patojen varlığı çalışmasında incelediği 100 adet karkas numunesinde Salmonella spp. varlı̆̆ına rastlamamıştır. Yine sığır karkaslarının mikrobiyal kontaminasyonunun belirlenmesi amaciyla yapılan bir çalışmada incelenen 60 adet karkas numunesinin hiçbirisinde Salmonella spp. izole edilememiştir [19]. Iyer ve ark. [12] tarafindan Suudi Arabistan'da yapılan bir çalışmada hipermarketten temin ettikleri 20 adet et örneğinde 1 tane (\% 5), kasaplardan temin ettikleri 20 adet et örneğinde ise 9 tanesinde (\% 45) Salmonella spp. varlığına rastladıklarını bildirmişlerdir. David ve ark. [7]'nın Avustralya'da yaptıkları çalışmada 360 adet kırmızı et örneğinin 4 tanesinde (\% 1.1) Salmonella spp. varlığına rastlanılmıştır.

Çöp şişin yapımında kullanılan kırımızı etin, hayvanın kesimi, derisinin yüzülmesi, iç organların çıkartılması, parçalanması, soğutulması, muhafaza edilmesi ile şekillenen kontaminasyon riski çöp şişin mikrobiyal yükünü etkilemektedir. Sağlıklı kasaplık hayvanların kesim öncesi durumları da dikkate alındığında etin mikroflorası ve kontaminasyon durumu özellikle kesimden sonraki aşamalarda önem taşımaktadır. Özellikle mezbahalardaki ve gida işletmelerindeki personel, kullanılan alet ve ekipmanlar, karkasın taşınması, depolanması, soguk zincirin korunmaması mikrobiyel bulaşmada önemli potansiyel kaynak oluşturmaktadır. Karkasın parçalandıktan sonra çöp şiş için etlerin küçültülerek yüzey alanlarının genişletilmesi de mikrobiyel açıdan etin yükünü arttıran bir unsur olmaktadır.

Aydın ilinde satışa sunulan çöp şişlerin mikrobiyolojik kalitesinin istenilen düzeyde olmamas1, halk sağlı̆̆1 açısından potansiyel bir risk teşkil etmektedir. Buna ek olarak çöp şişlerin yeterli 1sıl işlem görmeden tüketilmesi, çapraz kontaminasyon olması halinde sağlık açısından risk oluşturabilmektedir. Sağlıklı çöp şiş üretimi sağlayabilmek amacıyla öncelikle kesimhanede sağlıklı ve veteriner hekim kontrolünden geçmiş hayvan kullanılması, kesimin ve üretimin her aşamasında personelin gerekli hijyen kurallarına uyması açısından bilinçlendirilmesi, kesim ve parçalama işlemlerinin sonunda muhafaza koşullarına dikkat edilmesi, özellikle yaz aylarının oldukça sıcak geçtiği Aydın ilinde kırmızı etin çöp şiş restoranlarına taşınması aşamasında gereken soğuk zincirin korunması ve pişirme işlemine kadar gereken soğuk muhafazanın sağlanması, çöp şişlerin hazırlanması aşamasında özellikle personelin elinden kaynaklanan bulaşmaları önlemek amac1yla personele gerekli eğitimin verilmesi, yine çöp şişlerin hazırlanması aşamasında çapraz kontaminasyonun önlenmesi amacıyla pişmiş ve çiğ etlerin temasının önlenmesi ve bunlarla ilgili tedbirlerin alınması gerektiğinin sonucuna varılmıştır.

\section{Kaynaklar}

1. Akan İM, (2009). Et ve Bazı Et Ürünleri ile Soğuk Hava Depolarında Pseudomonas Türlerinin İzolasyonu ve İdentifikasyonu. Yüksek Lisans Tezi, Selçuk Üniversitesi Sağl1k Bilimleri Enstitüsü. Konya 2009, 56.

2. Al-Jasass FM, (2013). Assessment of the Microbial Growth and Chemical Changes in Beef and Lamb Meat Collected From Supermarket and Shop During Summer and Winter Season. Res J Recent Sci. 2(4), 20-27.

3. Aydemir Atasever M, Atasever M, (2015). Klymalarda bazı patojenlerin izolasyon ve identifikasyonu. İÜ Vet Fak Derg. 41(1), 60-68.

4. Bostan K, Yılmaz F, Muratoğlu K, Aydın A, (2011). Pişmiş döner kebaplarda mikrobiyolojik kalite ve mikrobiyel gelişim üzerine bir araştırma. Kafkas Univ Vet Fak Derg. 17 (5), 781-786.

5. Cohen N, Ennaji H, Hassa M, Karib H, (2006). The bacterial quality of red meat and offal in Casablanca (Morocco). Mol Nutr Food Res J. 50, 557-562.

6. Çitak S, Gündoğan N, Kala E, (2009). Ankara ilindeki dondurulmuş et ve sebzelerde koliform ve enterokoklarin fekal indikatör bakteri olarak değerlendirilmesi. Türk Hij Den Biyol Derg. 66(4), 145-151.

7. David P, David J, Stephen M, lan J, John S, (2008). A national survey of the microbiological quality of retail raw meats in Australia. J Food Protect. 6, 1232-1236.

8. Ertaş N, Yıldırım Y, Karadal F, Al S, (2013). Hayvansal gldalarda Escherichia coli O157 H7'nin önemi. Erciyes Üniv Vet Fak Derg. 10(1), 45-52.

9. Halkman K, (2005). Gida Mikrobiyolojisi Uygulamaları. Başak Matbaacılık, Ankara. 358.

10. Hauge SJ, Wahlgren M, Rotterud OJ, Nesbakken T, (2011). Hot water surface pasteurisation of lamb carcasses: microbial effects and cost-benefit considerations. Int J Food Microbiol. 146 (2011), 69-75.

11. Hughes FA, Adu-Gyamfi A, Appiah V, (2015). Microbiological and parasitological quality of local beef retailed in accra and radiation sensitivity of Salmonella spp. Int J Curr Microbiol Appl Sci. 4(4), 86-96.

12. Iyer A, Kumosani1 T, Yaghmoor S, Barbour E, Azhar E, Harakeh S, (2013). Escherichia coli and Salmonella spp. in meat in Jeddah, Saudi Arabia. J Infect Devel Count. 7 (11), 812-818. 
13. Kıvanç B, Kunduoğlu B, (1996). Eskişehir'de tüketilen köftelerin mikrobiyolojik incelenmesi ve halk să̆lı̆̆ açısından önemi. AÜ Fen Fak Derg. 1, 5-15.

14. Koçak P, (2013). Aydın İlindeki Mandıralarda Üretilip Satışa Sunulan Beyaz, Tulum, Kaşar ve Lor Peynirlerinin Mikrobiyolojik Kalitesinin Araștırılması. Yüksek Lisans Tezi, Adnan Menderes Üniversitesi Sağlık Bilimleri Enstitüsü. Aydın, 77.

15. Mohamed EAA, (2007). The Microbiological Load of Fresh and Processed Meat. Univ Vet Med. 163.

16. Nursoy G, Akgün S, (1997). Ankara'daki askeri birliklerin ihtiyacı için alınan sığır etlerinin mikrobiyolojik kaliteleri üzerinde araştırmalar. Gıda Derg. 22(3), 241-245.

17. Oxoid, (2006). The Oxoid Manual 9th, Oxoid Limited, England. 624.

18. Öksüztepe G, Güran HŞ, İncili GK, Gül SB, (2011). Elazığ'da tüketime sunulan fermente sucukların mikrobiyolojik ve kimyasal kalitesi. Firat Üniv Sağl Bil Vet Derg. 25(3), 107-114.
19. Özdemir H, (2007). Si ̆̆ır Karkaslarında Mikrobiyel Yüzey Kontaminasyonunun Belirlenmesi. Bilimsel Araştırma Projesi Kesin Raporu. 20070810008HPd, Ankara, s11.

20. Özmen S, (2002). Çanakkale İlindeki Mezbahaların Kritik Kontrol Noktalarından Alinan Numunelerde Koliform, Escherichia coli ve Escherichia coli O157:H7 Varlı̆̆ Üzerine Araştırmalar. Yüksek Lisans Tezi, Çanakkale Onsekiz Mart Üniversitesi Fen Bilimleri Enstitüsü, Çanakkale. 2002, 76.

21. Thomas N, Pal M, Aylate A, (2015). Bacteriological quality of raw meat collected from municipality slaughter house and local marketa in and around Wolaita Soddo Town, Southern Ethiopia. Vet Health Sci Res. 3(8), 75-81.

22. Tuncer BH, (2008). Bitlis ili ve çevresindeki askeri mutfaklarda kullanılan sığır gövde etlerinde bazı patojenlerin varlı̆̆ı. Yüksek Lisans Tezi, Yüzüncü Y1l Üniversitesi Sağl1k Bilimleri Enstitüsü. Van 2008, 72.

23. Web_1,(2016). http://ziyafetgrup.com/index.php?icerik=213\&goster $=214,12.09 .2016$. 